Eurasian Journal of Business and Economics 2016, 9 (17), 153-164.

\title{
Mode of Entry and the Performance of Foreign Banks: Evidence from Turkish Banking Industry
}

\author{
Ahmet AKIN $^{*}$, Nizamettin BAYYURT ${ }^{* *}$
}

\begin{abstract}
Emerging economies have been attracting considerable amount of foreign direct investments to the banking industry through cross-border acquisitions and new establishments. Whether mode of entry influences the performance of foreign banks is an important question. This study analyzes the impact of entry mode on the foreign bank performance in Turkey for the period before and after the global financial crisis. Profitability and relative efficiencies are used to measure the performance of banks. Then, Tobit and multivariate regressions are performed to detect the performance differentials between the bank groups. Analysis reveals that greenfield banks have superior performance over the takeover banks in terms of only profitability. Mode of entry does not have a statistically significant effect on efficiency. Besides, there are no efficiency or profitability gains for takeover banks after acquisition.
\end{abstract}

Keywords: Foreign acquisition, Greenfield investment, Profitability, Efficiency, Banks

JEL Code Classification: D24, G21, G34,

UDC: 336.71

DOI: https://doi.org/10.17015/ejbe.2016.017.09

\footnotetext{
Corresponding Author. Associate Professor, Faculty of Economic and Administrative Sciences, Fatih University, Istanbul, Turkey. E-mail: akin@fatih.edu.tr

** Professor, Faculty of Management, Istanbul Technical University, Istanbul, Turkey.

E-mail: bayyurt@itu.edu.tr
}

Copyright (C, 2016 International Ataturk Alatoo University. 


\section{Introduction}

Banking industry, especially the ones in the developing countries have been attracting considerable amount of foreign direct investment. Eventually, foreign banks have become one of the major players. According to the bank ownership database compiled by Claessens and Van Horen (2014), the number of foreignowned banks increased by 69\% from 1995 to 2009. Besides, relative share of foreign banks in terms of number increased to 34\% in 2009 from $20 \%$ in 1995. Parallel with the increasing importance of foreign banks, performance differentials between foreign and domestic banks have become a hot topic and widely studied. Most of the empirical studies find that foreign banks have superior performance in emerging markets and inferior performance in developed countries (Berger, 2007; Lensink, Meesters, \& Naaborg, 2008). Superior performance of foreign banks in developing countries requires further analysis. Foreign banks may enter host country through cross border lending, greenfield investment or a domestic bank acquisition. A question arises here: How does the entry mode affect the performance of foreign banks. Answer for this question will influence the entry strategy of bank to foreign markets and banking authorities' decision on the entry mode of foreign banks.

This study analyzes the impact of entry mode on the foreign bank performance in an emerging economy, Turkey for the period before and after the global financial crisis. Turkey is fully liberalized emerging economy in which foreign banks can operate. Ownership structure of Turkish banks has changed quite a lot recently due to the foreign acquisitions. Comparative performance of foreign banks versus domestic banks has been studied for Turkish banking sector (Akin, Bayyurt, \& Zaim, 2013; Aysan \& Ceyhan, 2008; Fukuyama \& Matousek, 2011; Isik \& Hassan, 2002; Mercan, Reisman, Yolalan, \& Emel, 2003). However, impact of entry mode on the performance of foreign banks in Turkey is mainly ignored. Therefore, whether the entry mode - foreign acquisition versus foreign greenfield investment -influences the performance of foreign banks in Turkey deserves careful examination. Most study measures the performance by either some accounting ratios or efficiency. We use both profitability measured by return on asset (ROA) and relative efficiencies obtained by Data Envelopment Analysis (DEA). Then, Tobit and multivariate regressions are performed to detect the performance differentials between the greenfield and takeover banks. Besides, any performance gains after foreign acquisition are also investigated. Our results imply that foreign greenfield banks have better performance than takeover banks. However, we could not detect statistically significant profitability or efficiency gains for the takeover banks after acquisition.

The remainder of the study is as follows. Section 2 is the literature review of studies related to the performance of foreign banks and effect of entry mode on their performances. Section 3 introduces the Turkish Banking Industry briefly and section 4 describes the data as well as the methodology. Statistics for profitability and 
Mode of entry and the performance of foreign banks: Evidence from Turkish Banking...

efficiency of foreign banks are presented in section 5 . Effect of entry mode on the performance is discussed in section 6 . Conclusion is the final section.

\section{Literature Review}

Performance of foreign banks is analyzed in the literature from different aspects. A group of studies for developing countries focuses on the performance differentials of banks under state, domestic, and foreign ownership. Foreign banks are more efficient than domestic, state, and private banks in developing and transitional countries according to most studies. For instance, reviews of Lensink et al. (2008) and Berger (2007) show that foreign owned banks have higher efficiency than domestic banks in developing countries. Bonin, Hasan, and Wachtel (2005) bring evidence of superior efficiency of foreign banks from 11 transition countries while Fries and Taci (2005) find that privatized banks with majority foreign ownership are the most efficient banks in 15 transition countries. Micco, Panizza, and Yanez (2007) also support the findings for the superior performance of foreign banks in developing countries. Besides, foreign banks are found to be more efficient in China by Berger, Hasan, and Zhou (2009), in Malaysia by Sufian (2009) , Bulgaria by Tochkov and Nenovsky (2011), and Turkey by Akin et al. (2013).

Some other studies analyze the conditions for the most favorable entry modes of foreign banks. Lehner (2009) shows that there is an optimal entry mode for foreign banks. Size and financial development level of host banking market matter for the choice of entry mode. According to her model, cross-border lending, and acquisition dominates in less developed market; however, developed markets favor greenfield entry. Besides, she shows that there is a tendency towards acquisition entry in smaller host countries and greenfield entry in larger host countries. Hryckiewicz and Kowalewski (2010) find that economic situation in the home and host countries influences the entry mode of foreign banks into emerging markets. For instance, during the global expansion period, changes in the exchange rates between the host and home country play an important role. Entry through acquisition is favored if host country's currency depreciates, otherwise greenfield investments or branch offices should be preferred. Cerutti, Dell'Ariccia, and Martínez Pería (2007) study the organizational forms of world's top 100 international banks for their operations in Latin America and Eastern Europe. They examine the factors which affect the international banks to operate as a subsidiary or a branch. They find that taxes, regulatory restrictions, penetration strategy for retail operations as well as economic and political risks are determinants of organizational form.

Whether mode of entry influences the foreign banks' performance is also examined by several empirical studies. Results are mixed. Havrylchyk and Jurzyk (2011a) observe positive performance gains on the acquired banks in terms of efficiency in Eastern and Central Europe. Havrylchyk and Jurzyk (2011b) find that mode of entry affects the profitability of foreign banks in Central and Eastern European countries. 
While takeover banks do not differ from domestic banks in terms of profitability, ROA of greenfield banks is higher than that of other banks including the takeover banks. Havrylchyk (2006) also reaches a similar conclusion for the efficiency of foreign banks in Poland. Operational efficiency of acquired banks in Thailand is improved according to Okuda and Rungsomboon (2006). Isik (2008) analyzes the efficiency and productivity of de novo banks in Turkey. He finds that de novo banks tend to outperform established banks. Besides he shows that foreign entries are more efficient and they perform higher productivity growth than domestic ones. On the other hand, Berger, Clarke, Cull, Klapper, and Udell (2005) find relatively little performance change in the banks after foreign acquisitions in Argentina. According to Barros and Williams (2013), foreign acquisitions during the Mexico's bank restructuring programme of 1995 does not significantly affect bank cost efficiency. Havrylchyk (2006) shows that foreign acquisition do not contribute to the efficiency of banks in Poland. Only little performance change is detected by Lin and Zhang (2009) for the banks in China after foreign acquisition.

\section{Brief information banking sector in Turkey}

Number of banks in Turkey fluctuated during the years. It increased from 43 to 85 from 1980 to 2000. However, financial crisis of 2001 led to a decrease in the number of banks and there were 51 banks at the end of 2005. We witnessed a stable period thereafter. As the end of 2015, a total of 50 banks are operating in Turkey, and the deposit banks are higher in number. There are 32 deposit banks, 13 development and investment banks, and 5 participatory banks. Number of foreign deposit banks exceeded the private domestic banks after 2005 through acquisition of domestic banks and new establishments and it reached to 21 at end of 2015 . Besides, 8 private-domestic banks and 3 state banks are operating in Turkey.

Table 1. Number of Banks in Turkey

\begin{tabular}{lcccccc}
\hline Bank Type/Year & 1980 & 1990 & 2000 & 2005 & 2010 & 2015 \\
\hline Deposit Banks & 40 & 56 & 61 & 34 & 32 & 32 \\
State & 12 & 8 & 4 & 3 & 3 & 3 \\
Private- domestic & 24 & 25 & 28 & 17 & 11 & 8 \\
Foreign & 4 & 23 & 18 & 13 & 17 & 21 \\
Saving Deposit Insurance Fund & - & - & 11 & 1 & 1 & - \\
Development and Investment Banks & 3 & 10 & 18 & 13 & 13 & 13 \\
Participatory Banks & - & 3 & 6 & 4 & 4 & 5 \\
\hline Total & 43 & 69 & 85 & 51 & 49 & 50 \\
\hline
\end{tabular}

Source: Bank Association of Turkey (2016a).

When we consider the breakdown of total assets, loans, and deposits of banking industry with respect to bank types, we see that deposit banks have the highest share ranging from $90 \%$ to $94 \%$. Share of other bank types are relatively small. Within the domestic banks, private-domestic banks have the highest share. Although there are only 3 state banks, their share in the banking sector is considerably high. On the other hand, foreign banks are high in number but have 
Mode of entry and the performance of foreign banks: Evidence from Turkish Banking...

smaller share in the banking sector. Thus, average size of foreign banks is smaller than that of public and private-domestic banks.

Table 2. Breakdown of Selected Indicators with Respect to Bank Type (\%) in 2015

\begin{tabular}{lrcc}
\hline Bank Type & Assets & Loans & Deposits \\
\hline Deposit Banks & 91 & 90 & 94 \\
State & 29 & 29 & 31 \\
Private- domestic & 36 & 36 & 37 \\
Foreign & 25 & 26 & 27 \\
Development and Investment Banks & 5 & 5 & - \\
Participatory Banks & 5 & 5 & 6 \\
\hline Total & 100 & 100 & 100 \\
\hline
\end{tabular}

Source: Bank Association of Turkey (2016b).

\section{Data and Methodology}

We use the 2002-13 data sets of commercial banks in Turkey. Investment and development banks and participating banks are excluded from our analysis. We collect the data from website of the Banks Association of Turkey. We follow the previous studies in the literature and classify banks as foreign if foreign ownership is above $50 \%$ (de Haas \& van Lelyveld, 2006; Fungáčová, Herrala, \& Weill, 2013; Havrylchyk, 2006; Havrylchyk \& Jurzyk, 2011a; Micco et al., 2007). Thus, when foreigners acquire $50 \%$ or more share in a domestic bank, this bank is classified as a takeover bank.

Relative efficiencies and return on assets (ROA) are used to measure the performance of banks. In order to determine effect of entry mode of foreign banks on the performance, separate regressions are run for relative efficiencies and ROA. Regression equations are specified as follows:

$$
Y_{i}=\alpha+\beta_{1} D_{1 i}+\beta_{2} D_{2 i}+\gamma X_{i}+e_{i}
$$

where $Y_{i}$ refers to performance measurement. $D_{1 i}$ is the dummy variable for foreign greenfield banks and $D_{2 i}$ is the dummy variable for domestic banks where the banks acquired by foreigners are the base dummy. Besides $X_{i}$ is a vector of the following control variables.

- Loans: Loans divided by assets

- Size: Natural logarithm of assets

- Capital: Equity divided by assets

- Profitability (used in Tobit regression): Net income divided by total assets (ROA)

- Number of years after acquisition: The year in which acquisition takes place is counted as zero.

- Year Dummies: Separate dummy variables are used for each of the years from 2008 to 2010, and a dummy variable for the years after 2010 (base dummy is the years before 2008). 
Relative efficiencies are obtained by Data Envelopment Analysis and ROAs are calculated as net income divided by total assets. While multivariate regression is run for ROA, Tobit regression is performed when dependent variable is the relative efficiency because Tobit regression can account for truncated data. DEA scores are limited to the interval $[0 ; 1]$. Therefore, Tobit Model is the most suitable model when the dependent variable is limited or censored from below and/or above. The use of OLS regression on such a censored distribution produces biased estimates and invalid inferences (Greene, 1997; Maddala, 1983). Tobit regression is known as more appropriate for censored dependent variables (Tobin, 1958; Wooldridge, 2006).

Before the panel data analysis, we test whether the series are stationary. When regressors are nonstationary empirical results of the time series are not valid. Therefore, unit root tests are important in examining the stationarity of panel data due to the time component. In order to find out the stationarity of the series, we apply Fisher's test based on augmented Dickey-Fuller test since our data is not balanced panel and Fisher's test does not require a balanced panel data. Fisher's test assumes that all series are non-stationary under the null hypothesis against the alternative that at least one series in the panel is stationary. The results of the test are given on Table 4 . The outcome of the test statistics $\left(P, Z, L^{*}, P m\right)$ to test the hypothesis and their associated $p$-value are seen in the table. All of the $p$-values are relatively small. A $5 \%$ level of statistical significance, we can see that all of your $p$ values are smaller than this threshold. So on the basis of this we can reject the null hypothesis. This means that our panel data does not contain a unit root. The series in our panel data are stationarity.

On the other hand, we test serial correlation problem by Wooldridge test for autocorrelation in panel data. This test assumes that there is no first order autocorrelation under the null hypothesis against the alternative that there is autocorrelation in the model. The results for efficiency model reveals that $[F(1,34)$ $=1.336$, Prob $>F=0.2557$ ] the null hypothesis could not be rejected. However, the test rejects the null hypothesis for the ROA model $[F(1,34)=8.298$, Prob $>F=$ 0.0068 ] so we can assume that there is no serial correlation in efficiency model but in ROA.

In addition to the unit root and serial correlation tests we also test heteroskedasticity along with the panels for efficiency and profitability models by Poi and Wiggins (2001) suggestion of LR test (Likelihood-ratio test) for panel-level heteroskedasticity. When the null hypothesis is rejected in this test, it is accepted that heteroskedasticity is a problem in the model. The results of the test for efficiency model is Chi2(38) $=80.09$ and Prob $>$ chi2 $=0.0001$ and for profitability model, $\operatorname{chi} 2(38)=1069.71$, Prob $>$ chi2 $=0.0000$. Since we can reject null hypotheses in both models at $5 \%$ level of significance, we accept that there is heteroskedasticity problems in both models. 
Mode of entry and the performance of foreign banks: Evidence from Turkish Banking...

Table 3. Fisher-type unit-root tests based on augmented Dickey-Fuller tests

\begin{tabular}{lllll}
\hline & & & Statistic & p-value \\
\hline Efficiency & Inverse chi-squared(70) & $\mathrm{P}$ & 213.2602 & 0.000 \\
& Inverse normal & $\mathrm{Z}$ & -6.5928 & 0.000 \\
& Inverse logit t(174) & $\mathrm{L}^{*}$ & -8.8002 & 0.000 \\
& Modified inv. chi-squared & $\mathrm{Pm}$ & 12.1077 & 0.000 \\
\hline Profitability & Inverse chi-squared(70) & $\mathrm{P}$ & 308.3900 & 0.000 \\
& Inverse normal & $\mathrm{Z}$ & -10.1662 & 0.000 \\
& Inverse logit t(174) & $\mathrm{L}^{*}$ & -13.7923 & 0.000 \\
& Modified inv. chi-squared & $\mathrm{Pm}$ & 20.1476 & 0.000 \\
\hline Loan & Inverse chi-squared(70) & $\mathrm{P}$ & 309.4542 & 0.000 \\
& Inverse normal & $\mathrm{Z}$ & -6.5982 & 0.000 \\
& Inverse logit t(164) & $\mathrm{L}^{*}$ & -12.6839 & 0.000 \\
& Modified inv. chi-squared & $\mathrm{Pm}$ & 20.2376 & 0.000 \\
\hline Capital & Inverse chi-squared(70) & $\mathrm{P}$ & 304.5867 & 0.000 \\
& Inverse normal & $\mathrm{Z}$ & -8.0601 & 0.000 \\
& Inverse logit t(169) & $\mathrm{L}^{*}$ & -12.9522 & 0.000 \\
& Modified inv. chi-squared & $\mathrm{Pm}$ & 19.8262 & 0.000 \\
\hline Size & Inverse chi-squared(70) & $\mathrm{P}$ & 182.6152 & 0.000 \\
& Inverse normal & $\mathrm{Z}$ & -6.0400 & 0.000 \\
& Inverse logit t(174) & $\mathrm{L}^{*}$ & -6.8119 & 0.000 \\
& Modified inv. chi-squared & $\mathrm{Pm}$ & 9.5177 & 0.000 \\
\hline
\end{tabular}

$P$ statistic requires number of panels to be finite. Other statistics are suitable for finite or infinite number of panels.

Ho: All panels contain unit roots, Ha: At least one panel is stationary, Number of panels: 39, Avg. number of periods: 10.18

Due to the serial correlation and heteroskedasticty problems in the efficiency model, Tobit Multiplicative Heteroskedasticity Regression which provides heteroskedasticity corrected estimates was run. In profitability model, we used robust standard errors random effects model for the corrected estimates.

\section{Relative Efficiency and Profitability of Banks}

In this study, relative efficiency of banks is measured by Data Envelopment Analysis which is currently a leading methodology in operations research for performance evaluations. The main advantage of DEA is that it is a parameter-free approach. For each decision making unit (DMU), DEA constructs a comparable virtual firm consisting of a portfolio of other sample firms. Then, the relative performance of the firm can be determined. Other quantitative techniques such as regression analysis are parametric, that is it estimates a "production function" and assesses each firm's performance according to its residual relative to the fitted fixed parameters economy-wide production function (Lauterbach \& Vaninsky, 1999). Other advantages of DEA are mentioned in many studies in the operations research literature. Donthu and Yoo (1998) summarizes these advantages in their study. 
Following linear programming problem is presented and solved by DEA for each firm :

$$
\operatorname{Maxh}_{O}=\sum_{r=1}^{S} u_{r} Y_{r o}
$$

subjectto

$$
\begin{aligned}
& \sum_{i=1}^{m} v_{i} X_{i o}=1 \\
& \sum_{r=1}^{S} u_{r} Y_{r k}-\sum_{i=1}^{m} v_{i} X_{i k} \leq 0 \\
& u_{r}, v_{i} \geq \varepsilon, \quad k=1, \ldots ., n, \quad r=1, \ldots ., s \text { and } i=1, \ldots, m
\end{aligned}
$$

Where $X_{i j}$ and $Y_{r j}$ stand for the amount of $i^{\text {th }}$ input and $r^{\text {th }}$ output of $j^{\text {th }} \mathrm{DMU}$, respectively. $v_{i j}$ and $u_{r j}$ are the weights of $\mathrm{i}^{\text {th }}$ input and $\mathrm{r}^{\text {th }}$ output when $\mathrm{j}^{\text {th }} \mathrm{DMU}$ is under consideration. $n$ is the number of firms in the sample, $s$ is the number of outputs and $m$ is the number of inputs that the analyzed firm produces and utilizes respectively. $\varepsilon$ is a very small positive number which ensures that every input and output has a value greater than zero. The model assumes that there is a constant return to scale (CRS). According to CRS, output will be doubled if the inputs of a DMU are doubled according to CRS. In our study, we also assume constant returns to scale. Dual of this model is an input oriented model since it points out the inefficiencies in the input consumption of $\mathrm{DMU}_{0}$. DEA method seeks to identify technical inefficiency as a proportional reduction in input usage in the inputorientated models. Technical inefficiency can also be measured as a proportional increase in output production.

Three inputs and three outputs are used in the analysis. While our inputs are number of employees, fixed assets, deposits and other loanable funds; our outputs are credits, other earning assets, and off-balance sheet liabilities. Efficiency scores and ROA of banks are depicted on Table 4. Foreign banks, both takeover and greenfield banks, have superior performance than domestic banks in terms of efficiency, but lower in terms of profitability. Average efficiency of greenfield banks is higher than takeover banks. Besides, greenfield banks are on average slightly more profitable than acquired banks. Thus, our initial analysis shows that mode of entry affects the performance of foreign banks in favor of takeover banks. 
Mode of entry and the performance of foreign banks: Evidence from Turkish Banking...

Table 4. Efficiency and ROA statistics of sample data

\begin{tabular}{|c|c|c|c|c|c|c|c|c|c|c|}
\hline & \multicolumn{5}{|c|}{ Efficiency } & \multicolumn{5}{|c|}{ ROA } \\
\hline Bank type & $\mathrm{N}$ & Mean & Std. Dev. & Min & $\operatorname{Max}$ & $\mathrm{N}$ & Mean & Std. Dev. & Min & Max \\
\hline Takeover & 70 & 0.836 & 0.162 & 0.194 & 1.000 & 70 & 0.008 & 0.035 & -0.176 & 0.134 \\
\hline Greenfield & 115 & 0.876 & 0.182 & 0.344 & 1.000 & 115 & 0.022 & 0.039 & -0.161 & 0.147 \\
\hline Domestic & 212 & 0.810 & 0.176 & 0.237 & 1.000 & 212 & 0.014 & 0.066 & -0.632 & 0.322 \\
\hline Total & 397 & 0.83357 & 0.177074 & 0.19 & 1 & 397 & 0.015146 & 0.054566 & -0.63 & 0.32 \\
\hline ANOVA & & $F=5.40$ & & & & & $F=1.64$ & & & \\
\hline Test & & Sig $=0.005$ & & & & & Sig $=0.20$ & & & \\
\hline
\end{tabular}

\section{Performance of Takeover versus Greenfield Banks}

Table 5 displays the results of Tobit regression which analyses the factors affecting the efficiency of banks in Turkey. The main purpose of this regression is to detect the efficiency differentials of two bank groups, specifically takeover banks and greenfield banks and any efficiency gains after foreign acquisition. Efficiency of greenfield banks are relatively higher than that of the takeover banks. The efficiency differential between greenfield and takeover banks are $7.4 \%$ in favor of greenfield banks. However, this result is not statistically significant. Tobit regression shows that mode of entry does not have statistically significant effect on the efficiency. Regression analysis also indicate that acquisition does not result in the efficiency gains as the number of years after acquisition does not have a positive significant coefficient.

Table 5. Mode of entry and efficiency, Random Effects Tobit Regression results

\begin{tabular}{lllll}
\hline Efficiency & Coef. & Std. Er. & z & sig \\
\hline Greenfield dummy & 0.074 & 0.055 & 1.35 & 0.177 \\
Domestic dummy & -0.040 & 0.051 & -0.79 & 0.427 \\
Size & 0.011 & 0.006 & 2.01 & 0.044 \\
Profitability & 0.602 & 0.151 & 3.98 & 0.000 \\
Loans & 0.202 & 0.050 & 4.05 & 0.000 \\
Capital & 0.209 & 0.059 & 3.57 & 0.000 \\
\# of years after acquisition & -0.006 & 0.011 & -0.54 & 0.590 \\
Year dummy-2008 & 0.007 & 0.030 & 0.22 & 0.826 \\
Year dummy-2009 & -0.049 & 0.031 & -1.61 & 0.107 \\
Year dummy- 2010 & -0.191 & 0.031 & -6.18 & 0.000 \\
Year dummy >2010 & 0.037 & 0.022 & 1.66 & 0.097 \\
Constant & 0.547 & 0.099 & 5.51 & 0.000 \\
\hline
\end{tabular}

Regression analysis for ROA points out the superior performance of greenfield banks over the takeover banks as shown on Table 6. ROA of greenfield banks are on average $5.5 \%$ higher than that of takeover banks. Profitability differential is significant at $5 \%$. As a consequence, mode of entry influences the performance of banks in terms of profitability. On the other hand, analysis does not detect any 
statistically significant change in the profitability of takeover banks after the acquisition. Thus, there are no profitability gains after acquisition.

\begin{tabular}{|c|c|c|c|c|}
\hline Dep. Var.; ROA & $\mathrm{B}$ & Std. Err & $\mathrm{t}$ & Sig \\
\hline Greenfield dummy & 0.055 & 0.026 & 2.15 & 0.031 \\
\hline Domestic dummy & 0.028 & 0.018 & 1.60 & 0.109 \\
\hline Size & 0.010 & 0.003 & 3.09 & 0.002 \\
\hline Loans & 0.023 & 0.017 & 1.34 & 0.180 \\
\hline Capital & 0.104 & 0.032 & 3.24 & 0.001 \\
\hline \# of years after acquisition & 0.005 & 0.003 & 1.36 & 0.172 \\
\hline Year dummy-2008 & -0.003 & 0.010 & -0.25 & 0.800 \\
\hline Year dummy-2009 & -0.003 & 0.010 & -0.34 & 0.737 \\
\hline Year dummy-2010 & -0.015 & 0.011 & -1.34 & 0.181 \\
\hline Year dummy >2010 & -0.016 & 0.011 & -1.54 & 0.124 \\
\hline Constant & -0.195 & 0.062 & -3.17 & 0.002 \\
\hline
\end{tabular}

\section{Conclusion}

Financial markets have vital role on the economic wealth of the countries. Banks are the dominant institutions in the financial system. Therefore, well-functioning of banks is crucial. Ownership of banks are shown to affect the performance of banks. Majority of studies show that foreign ownership improves the banks performance in developing countries. Foreigners enter new markets by new bank establishment (de novo bank) or acquisition of local banks. It is important to know whether the entry mode matters for the performance. This knowledge would influence the entrance strategy of foreign banks to new markets. Besides, banking authorities may encourage foreigners to enter through a specific mode. Our study analyzes the performance differentials of foreign greenfield banks and banks acquired by foreigners in Turkish banking sector. Performance is measured by both profitability and relative efficiency. Foreign greenfield banks have better performance than takeover banks with respect to profitability. However, no significant difference between greenfield banks and takeover banks is detected in terms of efficiency. Analysis also indicates that acquisition of banks by foreigners does not lead to a statistically significant improvement on efficiency and profitability.

\section{References}

Akin, A., Bayyurt, N., \& Zaim, S. (2013). Managerial and technical inefficiencies of foreign and domestic banks in Turkey during the 2008 global crisis. Emerging Markets Finance and Trade, 49(3), 48-63.

Aysan, A. F., \& Ceyhan, Å. P. (2008). What determines the banking sector performance in globalized financial markets? The case of Turkey. Physica A: Statistical Mechanics and its Applications, 387(7), 1593-1602.

Bank Association of Turkey. (2016a). The Banking Sector in Turkey:1960-2015. Istanbul Bank Association of Turkey. (2016b). Banks in Turkey-2015. Istanbul 
Mode of entry and the performance of foreign banks: Evidence from Turkish Banking...

Barros, C. P., \& Williams, J. (2013). The random parameters stochastic frontier cost function and the effectiveness of public policy: Evidence from bank restructuring in Mexico. International Review of Financial Analysis, 30(0), 98-108. http://dx.doi.org/10.1016/j.irfa.2013.06.006

Bayyurt, N., \& Akın, A. (2014). Effects of Foreign Acquisitions on the Performance of Securities Firms: Evidence from Turkey. Procedia-Social and Behavioral Sciences, 150, 156161.

Berger, A. N. (2007). International Comparisons of Banking Efficiency. Financial Markets, Institutions \& Instruments, 16(3), 119-144. doi:10.1111/j.1468-0416.2007.00121.x

Berger, A. N., Clarke, G. R. G., Cull, R., Klapper, L., \& Udell, G. F. (2005). Corporate governance and bank performance: A joint analysis of the static, selection, and dynamic effects of domestic, foreign, and state ownership. Journal of Banking \& Finance, 29(8-9), 2179-2221. http://dx.doi.org/10.1016/i.jbankfin.2005.03.013

Berger, A. N., Hasan, I., \& Zhou, M. (2009). Bank ownership and efficiency in China: What will happen in the world's largest nation? Journal of Banking \& Finance, 33(1), 113-130. http://dx.doi.org/10.1016/j.jbankfin.2007.05.016

Bonin, J. P., Hasan, I., \& Wachtel, P. (2005). Bank performance, efficiency and ownership in transition countries. Journal of Banking \& Finance, 29(1), 31-53. http://dx.doi.org/10.1016/i.jbankfin.2004.06.015

Cerutti, E., Dell'Ariccia, G., \& Martínez Pería, M. S. (2007). How banks go abroad: Branches or subsidiaries? Journal of Banking \& Finance, 31(6), 1669-1692. http://dx.doi.org/10.1016/i.jbankfin.2006.11.005

Claessens, S., \& Van Horen, N. (2014). Foreign Banks: Trends and Impact. Journal of Money, Credit and Banking, 46(s1), 295-326. doi:10.1111/jmcb.12092

de Haas, R., \& van Lelyveld, I. (2006). Foreign banks and credit stability in Central and Eastern Europe. A panel data analysis. Journal of Banking \& Finance, 30(7), 1927-1952. http://dx.doi.org/10.1016/j.jbankfin.2005.07.007

Donthu, N., \& Yoo, B. (1998). Retail productivity assessment using data envelopment analysis. Journal of retailing, 74(1), 89-105.

Fries, S., \& Taci, A. (2005). Cost efficiency of banks in transition: Evidence from 289 banks in 15 post-communist countries. Journal of Banking \& Finance, 29(1), 55-81.

Fukuyama, H., \& Matousek, R. (2011). Efficiency of Turkish banking: Two-stage network system. Variable returns to scale model. Journal of International Financial Markets, Institutions and Money, 21(1), 75-91.

Fungáčová, Z., Herrala, R., \& Weill, L. (2013). The influence of bank ownership on credit supply: Evidence from the recent financial crisis. Emerging Markets Review, 15(0), 136-147. http://dx.doi.org/10.1016/j.ememar.2013.02.002

Greene, W. (1997). Econometric analysis . New jersey: Prenticei-Hall International: Inc.

Havrylchyk, O. (2006). Efficiency of the Polish banking industry: Foreign versus domestic banks. Journal of Banking \& Finance, 30(7), 1975-1996. http://dx.doi.org/10.1016/i.jbankfin.2005.07.009

Havrylchyk, O., \& Jurzyk, E. (2011a). Inherited or earned? Performance of foreign banks in Central and Eastern Europe. Journal of Banking \& Finance, 35(5), 1291-1302. http://dx.doi.org/10.1016/j.jbankfin.2010.10.007 
Havrylchyk, O., \& Jurzyk, E. (2011b). Profitability of Foreign Banks in Central and Eastern Europe: Does the Entry Mode Matter? Economics of Transition, 19(3), 443-472. http://onlinelibrary.wiley.com/journal/10.1111/\%28ISSN\%291468-0351/issues

Hryckiewicz, A., \& Kowalewski, O. (2010). Economic determinates, financial crisis and entry modes of foreign banks into emerging markets. Emerging Markets Review, 11(3), 205-228. http://dx.doi.org/10.1016/i.ememar.2010.05.003

Isik, I. (2008). Productivity, technology and efficiency of de novo banks: A counter evidence from Turkey. Journal of Multinational Financial Management, 18(5), 427-442. http://dx.doi.org/10.1016/j.mulfin.2007.11.004

Isik, I., \& Hassan, M. K. (2002). Technical, scale and allocative efficiencies of Turkish banking industry. Journal of Banking \& Finance, 26(4), 719-766. http://dx.doi.org/10.1016/S03784266(01)00167-4

Lauterbach, B., \& Vaninsky, A. (1999). Ownership structure and firm performance: Evidence from Israel. Journal of Management and Governance, 3(2), 189-201.

Lehner, M. (2009). Entry mode choice of multinational banks. Journal of Banking \& Finance, 33(10), 1781-1792.

Lensink, R., Meesters, A., \& Naaborg, I. (2008). Bank efficiency and foreign ownership: Do good institutions matter? Journal of Banking \&amp; Finance, 32(5), 834-844.

Lin, X., \& Zhang, Y. (2009). Bank ownership reform and bank performance in China. Journal of Banking \& Finance, 33(1), 20-29. http://dx.doi.org/10.1016/i.jbankfin.2006.11.022

Maddala, G. (1983). Qualitative and limited dependent variable models in econometrics: Cambridge: Cambridge University Press.

Mercan, M., Reisman, A., Yolalan, R., \& Emel, A. B. (2003). The effect of scale and mode of ownership on the financial performance of the Turkish banking sector: results of a DEAbased analysis. Socio-Economic Planning Sciences, 37(3), 185-202.

Micco, A., Panizza, U., \& Yanez, M. (2007). Bank ownership and performance. Does politics matter? Journal of Banking \& Finance, 31(1), 219-241.

Okuda, H., \& Rungsomboon, S. (2006). Comparative cost study of foreign and Thai domestic banks in 1990-2002: Its policy implications for a desirable banking industry structure. Journal of Asian Economics, 17(4), 714-737. http://dx.doi.org/10.1016/i.asieco.2006.06.012

Sufian, F. (2009). Determinants of bank efficiency during unstable macroeconomic environment: Empirical evidence from Malaysia. Research in International Business and Finance, 23(1), 54-77.

Tobin, J. (1958). Estimation of relationships for limited dependent variables. Econometrica: journal of the Econometric Society, 24-36.

Tochkov, K., \& Nenovsky, N. (2011). Institutional Reforms, EU Accession, and Bank Efficiency in Transition Economies: Evidence from Bulgaria. Emerging Markets Finance and Trade, 47(1), 113-129. doi:10.2753/ree1540-496x470107

Wooldridge, J. (2006). Introductory Econometrics: A Modern Approach. Thomson Southwestern. Mason/Ohio 